\title{
Morphology and preliminary biomechanical interpretation of mandibular sutures in Metoposaurus krasiejowensis (Temnospondyli, Stereospondyli) from the Upper Triassic of Poland
}

\author{
Kamil Gruntmejer ${ }^{1,2}$ ([) $\cdot$ Dorota Konietzko-Meier ${ }^{1,3}$ ([) $\cdot$ Adam Bodzioch $^{1} \cdot$ Josep Fortuny ${ }^{4,5}$ ()
}

Received: 23 September 2017 / Accepted: 1 June 2018 / Published online: 3 July 2018

(c) The Author(s) 2018

\begin{abstract}
The morphology of the mandibular sutures in the Late Triassic temnospondyl Metoposaurus krasiejowensis has been examined in order to determine their role in mandible biomechanics. Until now, no histological studies of mandibular sutures in extinct vertebrates were performed, in contrast to cranial sutures. As a consequence, mandibular suture interpretations herein are based mainly on comparisons with previous studies of cranial sutures and with 3D cranial finite element analysis of this species. A total of 32 standard thin sections were studied under standard petrographic microscope observations in order to differentiate the morphology of mandibular sutures. Five mandibular suture types are present in this taxon: interdigitated, shallowly interdigitated, overlapping, tongue and groove and abutting. Based on previous work, it has generally been assumed that the shallowly interdigitated, tongue, groove and abutting suture types are associated with tension, the interdigitated type with compression and the overlapping type with absorption and counteraction of variable loads. The sutures associated with tension occur mainly in the anterior part of the mandible, principally in the dentary; overlapping sutures have been noted in medial portions of the mandible and sutures associated with compression mainly in posterior portions, i.e., in the angular and prearticular. The variability of suture types along the mandible suggests a complex loading regime of compression and tension. Sutures associated with tension and a flexible symphysis potentially allowed an increase of oral volume during gape opening, whereas sutures associated with compression represent adaptations for strong bite forces.
\end{abstract}

Keywords Temnospondyli $\cdot$ Metoposaurus $\cdot$ Mandible $\cdot$ Sutures $\cdot$ Biomechanics

\section{Resumen}

Se ha examinado la morfología de las suturas mandibulares del temnospóndilo del Triásico Superior Metoposaurus krasiejowensis para determinar su papel en la biomecánica mandibular. Hasta la fecha, no se han realizado estudios histológicos de las suturas mandibulares de vertebrados fósiles, en contraste con los estudios histológicos en suturas craneales. Como consecuencia, las interpretaciones sobre las suturas mandibulares están aquí basadas en la comparación con estudios previos en suturas craneales y con análisis 3D de elementos finitos para esta misma especie. En total 32 laminas delgadas estándares fueron estudiadas con observaciones de microscopio petrográfico con el fin de diferenciar la morfología de las suturas mandibulares. Cinco tipos de suturas mandibulares son presentes en este taxón: interdigitales, levemente interdigitales, superposición, lengua, ranura y lindante. En base a estudios previos, se ha asumido generalmente que las suturas levemente interdigitales, lengua, ranura y lindantes se asocian con cargas de tensión, mientras que las de tipo interdigitales se asocian con compresión y el tipo sutural de superposición con distintas cargas de absorción y neutralización. Las suturas asociadas con tensión ocurren mayormente en la parte anterior de la mandíbula, principalmente en el dentario; las suturas de superposición se han encontrado las porciones mediales de la mandíbula y las suturas asociadas con compresión se han encontrado mayormente en las porciones posteriores, por ejemplo, en el angular y el prearticular. La variabilidad de los tipos suturales a lo largo de la mandíbula sugiere un complejo régimen de cargas de compresión y tensión. Suturas asociadas con tensión y una sínfisis flexible potencialmente permitieron un incremento del volumen oral durante la abertura bucal, mientras que las suturas asociadas con compresión representan adaptaciones a fuertes fuerzas de mordida.

Extended author information available on the last page of the article 
Palabras clave Temnospondyli $\cdot$ Metoposaurus $\cdot$ mandíbula $\cdot$ suturas $\cdot$ biomecánica

\section{Introduction}

With the exception of the small-sized taxon Apachesaurus, metoposaurids were large, around 2-3-m-long, aquatic temnospondyl amphibians with dorso-ventrally flattened bodies and large and parabolic skulls (Hunt 1993; Schoch and Milner 2000). The most characteristic anatomical features of the skull were the anterolateral position of the orbits (Hunt 1993). Metoposaurids had a cosmopolitan distribution during the Late Triassic. Skeletal remains of these temnospondyls are known from North America (Koskinonodon and Apachesaurus; Hunt 1993), North Africa (Dutuitosaurus ouazzoui and Arganasaurus lyazidi; Dutuit 1976; Hunt 1993), Madagascar (Dutuit 1978), India (Phantasaurus maleriensis; Chowdhury 1965, Sengupta 1992, 2002; Chakravorti and Sengupta 2016) and from Europe, including the following species: Metoposaurus diagnosticus (von Meyer 1842), Metoposaurus krasiejowensis- previously recognised as a subspecies, Metoposaurus diagnosticus krasiejowensis (see Sulej 2002), and Metoposaurus algarvensis (Brusatte et al. 2015). Material of the Polish taxon Metoposaurus krasiejowensis, recovered at Krasiejów, has been examined largely osteologically and histologically (Dzik et al. 2000; Sulej 2002, 2007; Dzik and Sulej 2007; Konietzko-Meier and Wawro 2007; Gruntmejer 2012; Konietzko-Meier and Klein 2013; Konietzko-Meier and Sander 2013; Konietzko-Meier et al. 2013, 2014; Brusatte et al. 2015; Gruntmejer et al. 2016; Konietzko-Meier et al. 2018; Teschner et al. 2018). However, quite of lot of unexplained issues surrounding the ecology and feeding of these animals remain. Previously, Metoposaurus was considered as an ambush predator, waiting for prey at the bottom of bodies of water (Ochev 1966; Murry 1989). Later, the capability of active swimming was considered to suggest that the feeding behaviour in metoposaurids was similar to that of extant crocodilians and alligators (i.e., "mid-water feeder") (Hunt 1993) and it was hypothesised that Metoposaurus was an active swimmer, using its limbs in the process (Sulej 2007). A histological analysis of intercentra has recently postulated that the long and laterally flattened tail was the main propulsion organ during swimming (Konietzko-Meier et al. 2013). From a different point of view, food acquisition has been discussed by different authors. Dzik et al. (2000) proposed that prey was captured by suction, whereas 3D-computational finite element analysis (FEA) of large temnospondyl taxa (e.g., capitosaurids) has revealed that these animals were active hunters, able to attack their prey by direct biting during swimming as well. It is because of the limited comparisons with extant taxa and demonstrating the peculiar ecological niche occupied by gigantic temnospondyl taxa (Fortuny et al. 2011, 2012, 2016; Marcé-Nogué et al. 2015). Recently, FEA studies of the European Metoposaurus krasiejowensis and the North American Apachesaurus gregorii have demonstrated that these temnospondyls were able to perform at least two types of biting, i.e., lateral biting utilized for active hunting during swimming, and bilateral biting for ambush hunting (Fortuny et al. 2017; Konietzko-Meier et al. 2018). However, all conclusions were based solely on analysis of the skull. No similar functional morphology studies of mandibles have been performed, with the exception of Sulej (2007) and the description of the mandibular dentition of Konietzko-Meier and Wawro (2007). Sulej (2007) described the presence of paired mentomandibular cartilage that connected the rami of the mandibles. The non-ossified junction allowed ventral bending of the mandibular rami during opening of the mouth. Later, Konietzko-Meier and Wawro (2007) indicated the presence of sharp edges on teeth which confirmed the ability for biting. Detailed studies of structures of sutures, of bone histology and interpretations of biomechanics based on finite element analysis are not available, not only for metoposaurids mandible, but generally among Temnospondyli. Most descriptions of mandibles focus on the localisation of the sutures and a general description of jaw morphology, but identifications of the nature and type of the inner suture are very rare. In most cases, their architecture along the bones is described, but not across the bone (e.g., Jupp and Warren 1986; Kathe 1995, 1997; Bolt and Chatterjee 2000; Ruta and Bolt 2008; Polley and Reisz 2011; Porro et al. 2015). Only Dutuit (1976) illustrated a cross section of the posterior part of the mandible of Dutuitosaurus ouazzoui, focusing on the articulation between the skull and mandible; however, no detailed information on the structure of the suture was provided.

\subsection{Sutures: morphology, types and function in vertebrates}

Absorption and dispersion of stress probably occurred mainly during feeding behaviour and were directly related with cranial and mandibular sutures. These structures are fibrous joints composed of collagen fibres that connect adjacent bones and provide biomechanical and growth functions (Jasinoski and Reddy 2012). The morphology of cranial sutures in extinct non-amniotes (fish and amphibians) holds valuable data for our understanding of cranial function during feeding (Markey et al. 2006). Most studies of the mechanical role of cranial sutures were conducted as in vivo stress measurements across sutures in extant vertebrates such as mammals, for example, Sus scrofa (Rafferty and Herring 1999) and actinopterygian fish such as Polypterus 
endlicherii (Markey and Marshall 2007a). These two phylogenetically widely separated groups inhabit different environments, with a diverse spectrum of prey capture. Actinopterygians obtain their food using a wide variety of methods, including suction feeding, ram feeding, filter feeding and biting (Markey et al. 2006). In contrast, in terrestrial settings almost all vertebrates (mammals, reptiles and amphibians) use practically a single technique of feeding, i.e., biting or, in herbivores, chewing. Despite these differences, sutures in fish and mammals exhibit closely similar stress patterns (Markey and Marshall 2007a). The interdigitated suture is characteristic of skull regions that experience high compressive loads, while shallowly interdigitated, abutting (or buttended) and tongue-and-groove sutures are associated with tension (Jasinoski et al. 2010a, b). The overlapping (or scarf) sutures represent a morphological compromise, which can accommodate both tensile and compressive stresses (Markey et al. 2006). Porro et al. (2015) distinguished a similar sutural morphology and biomechanical function in the skull of the Devonian Acanthostega gunnari. According to those authors, butt joints and tongue-and-groove joints are associated with tension, the interdigitated sutures with compression. In contrast to Markey et al. (2006), the scarf joints were defined as having been adapted to resist torsion and shear (Porro et al. 2015).

Moreover, the presence and arrangement of collagen fibres along the sutural edges also have a significant impact on stress distribution (Rafferty and Herring 1999; Herring and Teng 2000). In interdigitated sutures, which experience compression, the fibres are oriented obliquely in the direction of the apex of the interdigitation, while in shallowly interdigitated sutures, which experience tension, the fibres radiate outwards at the apex of the interdigitation, and some fibres have an oblique arrangement along the straight limbs of the sutural interdigitation (Rafferty and Herring 1999; Herring and Teng 2000; Jasinoski et al. 2010a). The presence of well-mineralised Sharpey's fibres on the sutural edges is a good indicator for differentiating these two types of sutural morphologies (Jasinoski et al. 2010b), and determine which bones contacts underwent compression or tension. Moreover, the occurrence of Sharpey's fibres is not limited to sutural edges. These structures indicate the point of attachment of skin, ligaments and skeletal muscles into the bone (Francillon-Vieillot et al. 1990). Sharpey's fibres are very numerous in the skull bones of Metoposaurus krasiejowensis, but are short and thin (Gruntmejer et al. 2016; Konietzko-Meier et al. 2018), whereas they are much thicker and longer in the mandible (Gruntmejer 2015).

Previous studies that focused on cranial sutures relied on correlations of sutural morphology and related biomechanical function among extant animals, using quantitative and computational research methodologies. Detailed descriptions of cranial suture morphology and its function in the dicynodonts Lystrosaurus declivis and Oudenodon bainii were also based on histological thin sections (Jasinoski et al. 2010b). Pioneer studies of the morphology and function of cranial sutures were those of Discosauriscus austriacus and Onchiodon labyrinthicus (Kathe 1995, 1997). Markey and Marshall (2007a) compared cranial suture morphology and its function in the extant Polypterus endlicherii, the Devonian Acanthostega gunnari and Eusthenopteron foordi and the Early Permian Phonerpeton pricei. Their goal was to evaluate at what moment in the fish-tetrapod transition suction feeding evolved into direct biting on prey. Their study revealed that suction feeders were characterised mainly by sutures associated with tension anteriorly and sutures associated with compression posteriorly, whereas animals capable of direct biting mostly showed only sutures associated with compression (Markey and Marshall 2007b).

In a similar manner to those studies, the morphology and assumed function of cranial sutures in the Late Triassic temnospondyl Metoposaurus krasiejowensis were studied histologically (Gruntmejer 2012). The presence of interdigitated sutures, which counteract compression loads, along the entire skull of Metoposaurus, may indicate direct biting on prey. Markey and Marshall (2007b) proposed the same way of feeding (biting) in Acanthostega gunnari. Data on the feeding behaviour in Acanthostega gunnari have been undermined following a 3D-computational analysis of their skull anatomy (Porro et al. 2015). Those studies revealed that the differentiation of sutural morphology in the skull of Acanthostega gunnari was more consistent with suction feeding, rather than with biting (Porro et al. 2015). Fortuny et al. (2015) proposed a correlation of cranial sutural function with biomechanical results derived from finite element analysis (FEA) on the extant Chinese giant salamander, Andrias davidianus, documenting the role of sutures to dissipate stress during feeding.

However, mandibular sutures and their biomechanical function in temnospondyls are still unknown and no taxa have been analysed to date. Similar to the skull, the mandible of Metoposaurus krasiejowensis is a conglomerate of ten bones (dentary, splenial, postsplenial, angular, surangular, articular, prearticular, coronoid, intercoronoid, precoronoid) that are adapted to resist various loads during feeding (Jupp and Warren 1986). Among non-amniote, extinct tetrapods, sutures and their biomechanical implications for the lower jaw have only been studied in the Devonian Acanthostega gunnari (Neenan et al. 2014; Porro et al. 2015). The mandibles of extinct taxa have been sectioned/histologically sampled (e.g., Carroll 1964; Heaton 1979; Haridy et al. 2017a, in press) but without a similar treatment or level of detailed study to that presented here. 


\subsection{Pursued goals}

Sutures play an important role in skull/mandible biomechanics. For this reason it is important to recognise the nature and function of the sutures along the lower jaw, not only on the morphological level, but also on the histological one. The main goal of the present study is to investigate, for the first time, mandibular sutural morphology in the Late Triassic temnospondyl Metoposaurus krasiejowensis using histological thin sections. Comparisons of mandibular sutural morphology in three specimens of Metoposaurus krasiejowensis are made in order to assess the variability of sutural typology along the entire mandible. Based on comparisons of suture morphology, interpretative functions of the mandibular sutures are proposed.

\section{Materials and methods}

\subsection{Material and geological setting}

The bony material used in the present study comes from the Upper Triassic bone bed at Krasiejów (southwest Poland). Disarticulated skeletal remains of large vertebrates (fishes, temnospondyls and archosaurs) occur in two horizons (Dzik and Sulej 2007; Sulej 2007; Gruszka and Zieliński 2008; Bodzioch and Kowal-Linka 2012). The stratigraphical age of the Upper Silesian Keuper is still a matter of debate. Stratigraphical data indicate that the bone bed at Krasiejów was deposited during the early Norian (Racki and Szulc 2014; Szulc et al. 2015a, b), whereas biochronological data suggest a late Carnian age (Dzik and Sulej 2007; Lucas et al. 2007; Lucas 2015).

Three mandibles of Metoposaurus krasiejowensis (all in the collections of Opole University, Department of Biosystematics, Laboratory of Palaeobiology; abbreviation: UOPB) have been studied histologically. UOPB 01145 (38 cm in length) is a complete, well-preserved left ramus (Fig. 1), while UOPB 01144 ( $9 \mathrm{~cm}$ in length) is a small piece of the symphysial part of the left ramus and UOPB $01027(34 \mathrm{~cm}$ in length) is a near-complete right hemimandible, albeit poorly preserved.

\subsection{Methods}

Three mandibular rami of Metoposaurus krasiejowensis were studied in order to obtain information on the structure of sutures, visible on the surface and in the cross sections. In total, 32 thin sections were studied histologically, 20 of UOPB 01145, seven of UOPB 01144 and the remaining five of UOPB 01027 (Fig. 1; Table 1). Overall, in thin sections, a total of 93 sutures were visible and histologically analysed (Table 2). Thin sections were prepared following

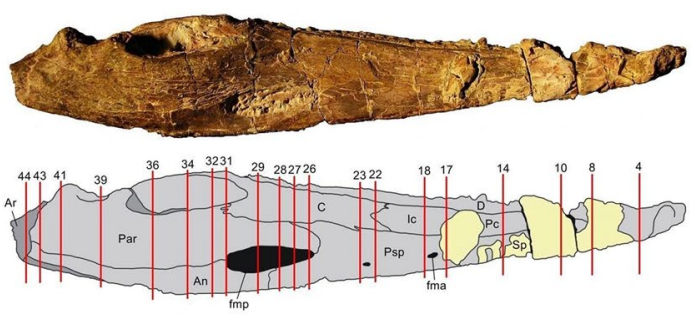

A UOPB 01145

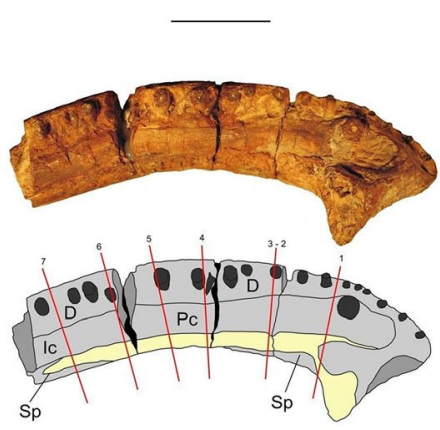

B UOPB 01144

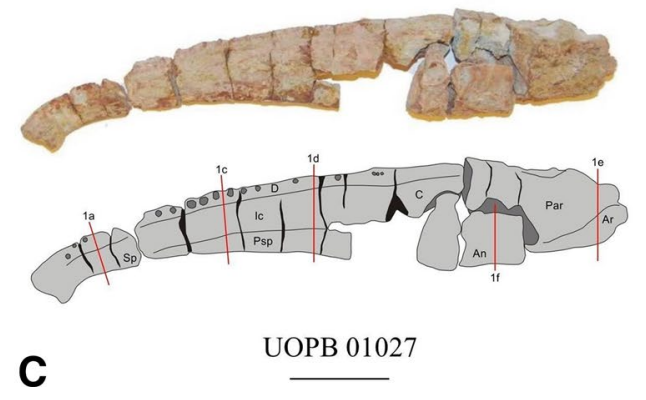

Fig. 1 Mandibles of Metoposaurus krasiejowensis (UOPB 01027, UOPB 01144 and UOPB 01145) from the Upper Triassic of Poland, and schematic drawings with marked locations of sectioning planes. The colour grey is used to indicate preserved parts of the mandible; damaged or matrix-covered regions are shown in light yellow. Scale bar equals $50 \mathrm{~mm}$. An angular, $A r$ articular, $C$ coronoid, $D$ dentary, $I c$ intercoronoid, Par prearticular, $P c$ precoronoid, $P s p$ postsplenial, $S p$ splenial, fma anterior Meckelian foramen, fmp posterior Meckelian foramen

standard petrographic procedures to a thickness of about 60-80 $\mu \mathrm{m}$ (Chinsamy and Raath 1992) at the Institute of Geology, Adam Mickiewicz University (Poznań, Poland). Qualitative observations on mandibular sutures in Metoposaurus krasiejowensis were made using a LEICA DMPL light microscope in plane and cross polarised light in order to differentiate their morphology. Schematic illustrations in cross sectional view of all sutural morphologies recognised in the mandible of Metoposaurus krasiejowensis are illustrated in Fig. 2. In cross section, the abutting suture is a contact between two relatively vertical edges of adjacent bones (Fig. 2a). The interdigitated suture is characterised by 
Table 1 The mandibular sutures analyzed in Metoposaurus krasiejowensis from the Late Triassic of Poland

\begin{tabular}{llllll}
\hline Sutures & $\begin{array}{l}\text { Anatomical } \\
\text { abbreviations }\end{array}$ & $\begin{array}{l}\text { Number of } \\
\text { samples }\end{array}$ & $\begin{array}{l}\text { Number of sutures examined in individual } \\
\text { specimens }\end{array}$ \\
\cline { 5 - 6 } & & \multicolumn{2}{l}{ UOPB 01145 } & UOPB 01144 & UOPB 01027 \\
\hline Angular-dentary & An-D & 7 & 6 & - & 1 \\
Angular-postsplenial & An-Psp & 6 & 5 & - & 1 \\
Angular-prearticular & An-Par & 6 & 5 & - & 1 \\
Angular-surangular & An-Sa & 6 & 6 & - & - \\
Articular-prearticular & Ar-Par & 3 & 2 & - & 1 \\
Articular-surangular & Ar-Sa & 3 & 2 & - & 1 \\
Coronoid-dentary & C-D & 7 & 6 & - & 1 \\
Coronoid-postsplenial & C-Psp & 3 & 2 & - & 1 \\
Coronoid-prearticular & C-Par & 6 & 6 & 2 & 1 \\
Dentary-intercoronoid & D-Ic & 6 & 3 & - & 1 \\
Dentary-postsplenial & D-Psp & 1 & - & 3 & 1 \\
Dentary-precoronoid & D-Pc & 6 & 2 & 7 & - \\
Dentary-splenial & D-Sp & 14 & 6 & - & 1 \\
Dentary-surangular & D-Sa & 2 & 2 & - & - \\
Intercoronoid-postsplenial & Ic-Psp & 1 & - & 2 & 1 \\
Intercoronoid-splenial & Ic-Sp & 5 & 3 & 3 & - \\
Postsplenial-splenial & Psp-Sp & 5 & 3 & 2 & - \\
Precoronoid-splenial & Pc-Sp & 6 & 2 & - & 1 \\
\hline & & & & 2 & - \\
\end{tabular}

complex and numerous deep interdigitating processes, where the adjacent bony edges dovetail into each other (Fig. 2b), while the shallowly interdigitated suture is characterised by low interdigitating processes (Fig. 2c). Moreover, the orientation of Sharpey's fibre arrangements on sutural edges is useful to distinguish these two latter sutural morphologies (see above). The tongue-and-groove suture is characterised by insertion of one bone into a groove of another (Fig. 2d). In the overlapping suture, the surfaces of adjacent bones greatly overlap each other without interdigitation (Fig. 2e).

We used thin sections with a large number of samples, combined with observations of suture morphology in superficial views. The advantage of this method is that histological details can be determined, such as orientation of collagen fibres, that normally are not visible in digital imaging.

Based on previous studies of cranial sutures in extant and extinct vertebrates (Rafferty and Herring 1999; Markey et al. 2006; Markey and Marshall 2007a, b; Jasinoski et al. 2010b; Porro et al. 2015), it was assumed that the biomechanical function of each sutural type could be correlated with the corresponding suture type in the mandible. Accordingly, interdigitated sutures of the mandible in Metoposaurus krasiejowensis are herein associated with compression (Rafferty and Herring 1999; Markey et al. 2006; Markey and Marshall 2007a, b; Jasinoski et al. 2010b; Porro et al. 2015), whereas the shallowly interdigitated, tongue-and-groove and abutting sutures are associated with tension (Markey et al. 2006; Jasinoski et al. 2010b; Porro et al. 2015) and the overlapping counteracted variable loads, i.e., with tension or compression (Markey et al. 2006; Jasinoski et al. 2010a) or torsion and shearing (Porro et al. 2015).

\section{Results}

\subsection{Description of mandibular sutural morphology in Metoposaurus krasiejowensis}

\subsubsection{Externally visible sutures}

Mandibular sutures between individual bones were externally discernible on the surface of the mandible (Fig. 3a-g). Sutural traces disappear in some places where the mandibles (especially in UOPB 01145) are covered by claystone matrix (Fig. 3a, f). Over the entire length of all analysed specimens, the external suture morphology appears as a straight-line connection between adjacent bones. The morphology of each suture is constant and usually does not change along the contact between individual bones, the sole exception being the upper area of the coronoid-prearticular suture on the lingual side where the straight trace of this suture becomes interdigitated (Fig. 3d). The coronoid-intercoronoid joint (Fig. 3b) and dentary-surangular suture (Fig. 3f) are visible as a tongue-and-groove connection. 
Table 2 Comparison of sutural morphology and its predicted stress resistance among three specimens

\begin{tabular}{|c|c|c|c|c|c|}
\hline Suture & Specimen & Number of sections & Morphology & Sharpey's fibres & Predicted stress \\
\hline An-D & UOPB 01145 & $22,23,26,27,28,29$ & Overlapping & Partly visible, oriented almost perpendicular & Variable stresses \\
\hline An-D & UOPB 01027 & $1 d$ & Overlapping & Partly visible, oriented almost perpendicular & Variable stresses \\
\hline An-Psp & UOPB 01145 & $22,23,26,27,28$ & Interdigitated & Well-visible, oblique oriented & Compression \\
\hline An-Psp & UOPB 01027 & $1 d$ & Interdigitated & Well-visible, oblique oriented & Compression \\
\hline An-Par & UOPB 01145 & $32,34,36,39,41$ & Interdigitated & Well-visible, oblique oriented & Compression \\
\hline An-Par & UOPB 01027 & 1f & Interdigitated & Well-visible, oblique oriented & Compression \\
\hline $\mathrm{An}-\mathrm{Sa}$ & UOPB 01145 & 31,32 & Overlapping & Partly visible, oriented almost perpendicular & Variable stresses \\
\hline $\mathrm{An}-\mathrm{Sa}$ & UOPB 01145 & $34,36,41,44$ & Interdigitated & Well-visible, oblique oriented & Compression \\
\hline Ar-Par & UOPB 01145 & 41,43 & Abutting & Well-visible, variable oriented & Tension \\
\hline Ar-Par & UOPB 01027 & $1 \mathrm{e}$ & Abutting & Well-visible, variable oriented & Tension \\
\hline $\mathrm{Ar}-\mathrm{Sa}$ & UOPB 01145 & 41,43 & Abutting & Well-visible, variable oriented & Tension \\
\hline $\mathrm{Ar}-\mathrm{Sa}$ & UOPB 01027 & $1 \mathrm{e}$ & Abutting & Well-visible, variable oriented & Tension \\
\hline C-D & UOPB 01145 & 22,23 & Tongue and groove & Poorly visible, orientation difficult to determine & Tension \\
\hline C-D & UOPB 01145 & $26,27,28,29$ & Shallowly interdigitated & Partly visible, slightly oblique oriented & Tension \\
\hline C-D & UOPB 01027 & $1 d$ & Tongue and groove & Poorly visible, orientation difficult to determine & Tension \\
\hline C-Par & UOPB 01145 & 26 & Interdigitated & Well-visible, oblique oriented & Compression \\
\hline C-Par & UOPB 01145 & $27,28,29$ & Overlapping & Partly visible, oriented almost perpendicular & Variable stresses \\
\hline C-Par & UOPB 01145 & 31,32 & Interdigitated & Well-visible, oblique oriented & Compression \\
\hline C-Psp & UOPB 01145 & 22 & Overlapping & Partly visible, oriented almost perpendicular & Variable stresses \\
\hline C-Psp & UOPB 01145 & 23 & Interdigitated & Well-visible, oblique oriented & Compression \\
\hline C-Psp & UOPB 01027 & $1 d$ & Interdigitated & Well-visible, oblique oriented & Compression \\
\hline D-Ic & UOPB 01145 & 14 & Shallowly interdigitated & Partly visible, slightly oblique oriented & Tension \\
\hline D-Ic & UOPB 01145 & 17,18 & Tongue and groove & Poorly visible, orientation difficult to determine & Tension \\
\hline D-Ic & UOPB 01144 & 6,7 & Tongue and groove & Poorly visible, orientation difficult to determine & Tension \\
\hline D-Ic & UOPB 01027 & $1 \mathrm{c}$ & Tongue and groove & Poorly visible, orientation difficult to determine & Tension \\
\hline D-Psp & UOPB 01027 & $1 \mathrm{c}$ & Overlapping & Visible, oriented almost perpendicular & Variable stresses \\
\hline D-Pc & UOPB 01145 & 8,10 & Shallowly interdigitated & Partly visible, slightly oblique oriented & Tension \\
\hline D-Pc & UOPB 01144 & $3,4,5$ & Shallowly interdigitated & Partly visible, slightly oblique oriented & Tension \\
\hline D-Pc & UOPB 01027 & $1 \mathrm{a}$ & Shallowly interdigitated & Partly visible, slightly oblique oriented & Tension \\
\hline $\mathrm{D}-\mathrm{Sa}$ & UOPB 01145 & 31,32 & Shallowly interdigitated & Partly visible, slightly oblique oriented & Tension \\
\hline $\mathrm{D}-\mathrm{Sp}$ & UOPB 01145 & $4,8,10,17,18$ & Shallowly interdigitated & Partly visible, slightly oblique oriented & Tension \\
\hline $\mathrm{D}-\mathrm{Sp}$ & UOPB 01145 & 14 & Tongue and groove & Poorly visible, orientation difficult to determine & Tension \\
\hline $\mathrm{D}-\mathrm{Sp}$ & UOPB 01144 & $1,2,3,4,5,6,7$ & Interdigitated & Well-visible, oriented almost perpendicular & Compression \\
\hline $\mathrm{D}-\mathrm{Sp}$ & UOPB 01027 & 1a & Shallowly interdigitated & Partly visible, slightly oblique oriented & Tension \\
\hline Ic-Psp & UOPB 01027 & $1 \mathrm{c}$ & Interdigitated & Well-visible, oblique oriented & Compression \\
\hline Ic-Sp & UOPB 01145 & 14 & Shallowly interdigitated & Partly visible, slightly oblique oriented & Tension \\
\hline Ic-Sp & UOPB 01145 & 17,18 & Interdigitated & Well-visible, oblique oriented & Compression \\
\hline Ic-Sp & UOPB 01144 & 6,7 & Shallowly interdigitated & Partly visible, slightly oblique oriented & Tension \\
\hline Pc-Sp & UOPB 01145 & 8,10 & Shallowly interdigitated & Partly visible, slightly oblique oriented & Tension \\
\hline Pc-Sp & UOPB 01144 & 3 & Shallowly interdigitated & Partly visible, slightly oblique oriented & Tension \\
\hline Pc-Sp & UOPB 01144 & 4,5 & Interdigitated & Well-visible, oblique oriented & Compression \\
\hline Pc-Sp & UOPB 01027 & $1 \mathrm{a}$ & Abutting & Poorly visible, orientation difficult to determine & Tension \\
\hline Psp-Sp & UOPB 01145 & 14 & Interdigitated & Well-visible, oblique oriented & Compression \\
\hline Psp-Sp & UOPB 01145 & 17,18 & Shallowly interdigitated & Partly visible, slightly oblique oriented & Tension \\
\hline Psp-Sp & UOPB 01144 & 6,7 & Interdigitated & Well-visible, oblique oriented & Compression \\
\hline
\end{tabular}

\subsubsection{Sutures visible in cross sections}

Five types of sutural morphology have been recognised in the mandible of this taxon: interdigitated, shallowly interdigitated, overlapping, tongue and groove and abutting (Table 2, Fig. 4).

Interdigitated sutures occur both on the labial and lingual sides of the mandible (Fig. 4). On the lingual part, this 
Fig. 2 Schematic profiles of different types of sutures recognised in the mandible of the Metoposaurus krasiejowensis. a Abutting suture; $\mathbf{b}$ interdigitated suture; $\mathbf{c}$ shallowly interdigitated suture; $\mathbf{d}$ tongue and groove suture; e overlapping suture

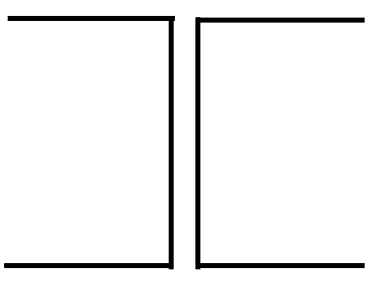

A

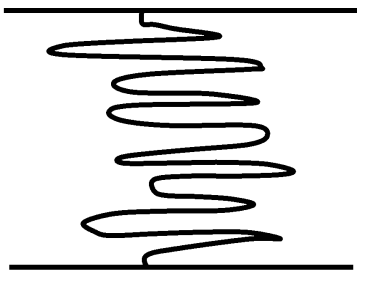

B

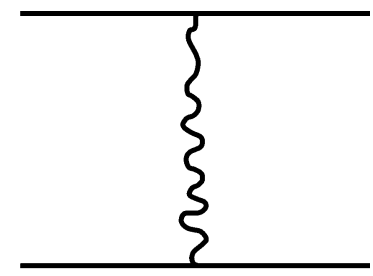

C

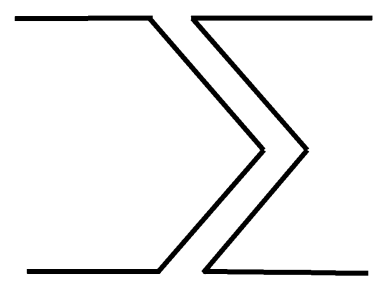

D

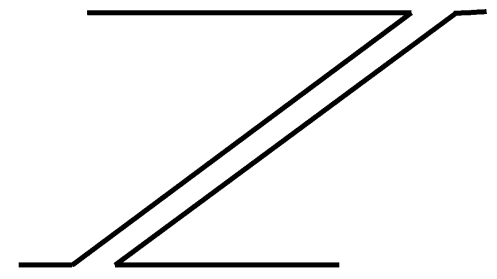

E

Fig. 3 External traces of mandibular sutures visible on the lingual (a-d, g) and labial surface $(\mathbf{e}, \mathbf{f})$. Scale bar equals $50 \mathrm{~mm}$. An angular, $C$ coronoid, $D$ dentary, $I c$ intercoronoid, $P a r$ prearticular, $P c$ precoronoid, $P s p$ postsplenial, $S a$ surangula, $S p$ splenial

A

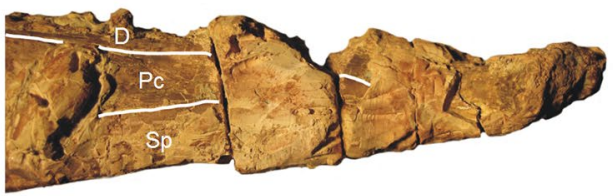

E

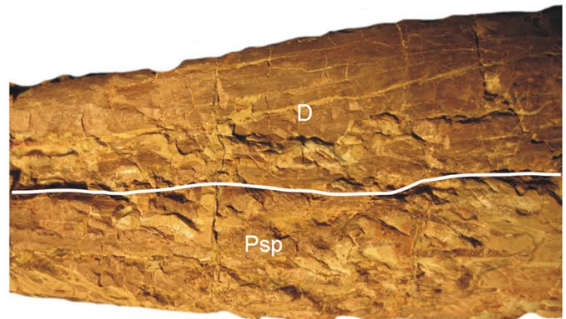

B

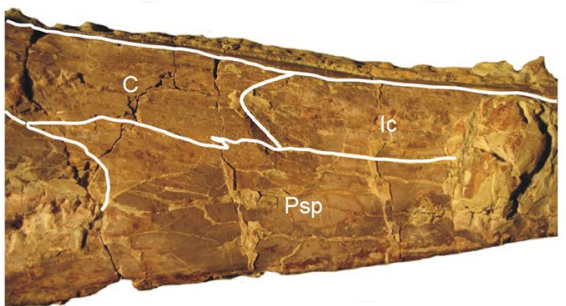

C

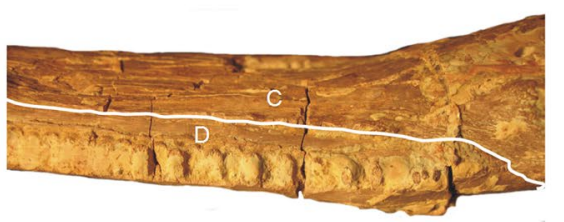

F

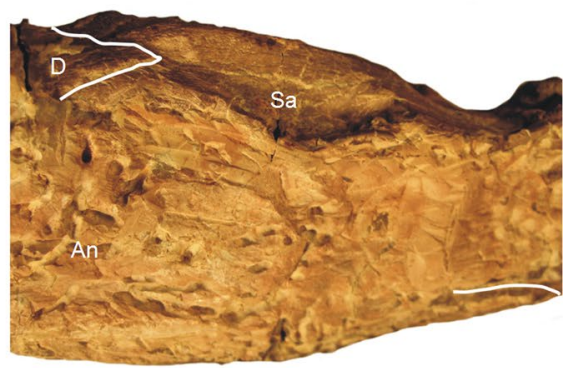

D
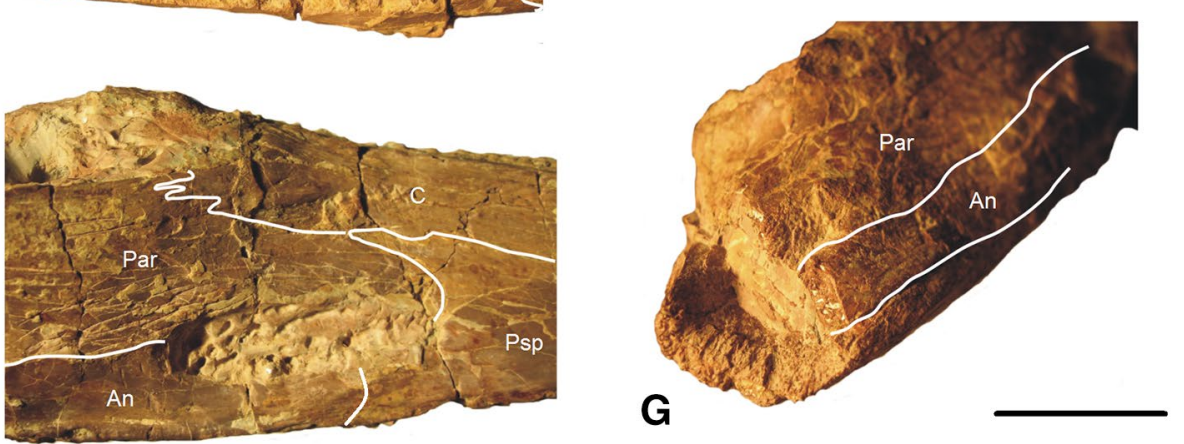

type of suture occurs at the following contacts: precoronoidsplenial (Fig. 5a, b), intercoronoid-postsplenial, coronoidpostsplenial, coronoid-prearticular, angular-prearticular (Fig. 5c, d) and angular-postsplenial. On the labial part, it can be observed at the dentary-splenial, angular-surangular (Fig. 5e) and angular-postsplenial contact (Fig. 5f). In some samples (e.g., UOPB 01144), an interdigitated suture has been noted at the postsplenial-splenial contact (Fig. 5g, h). 


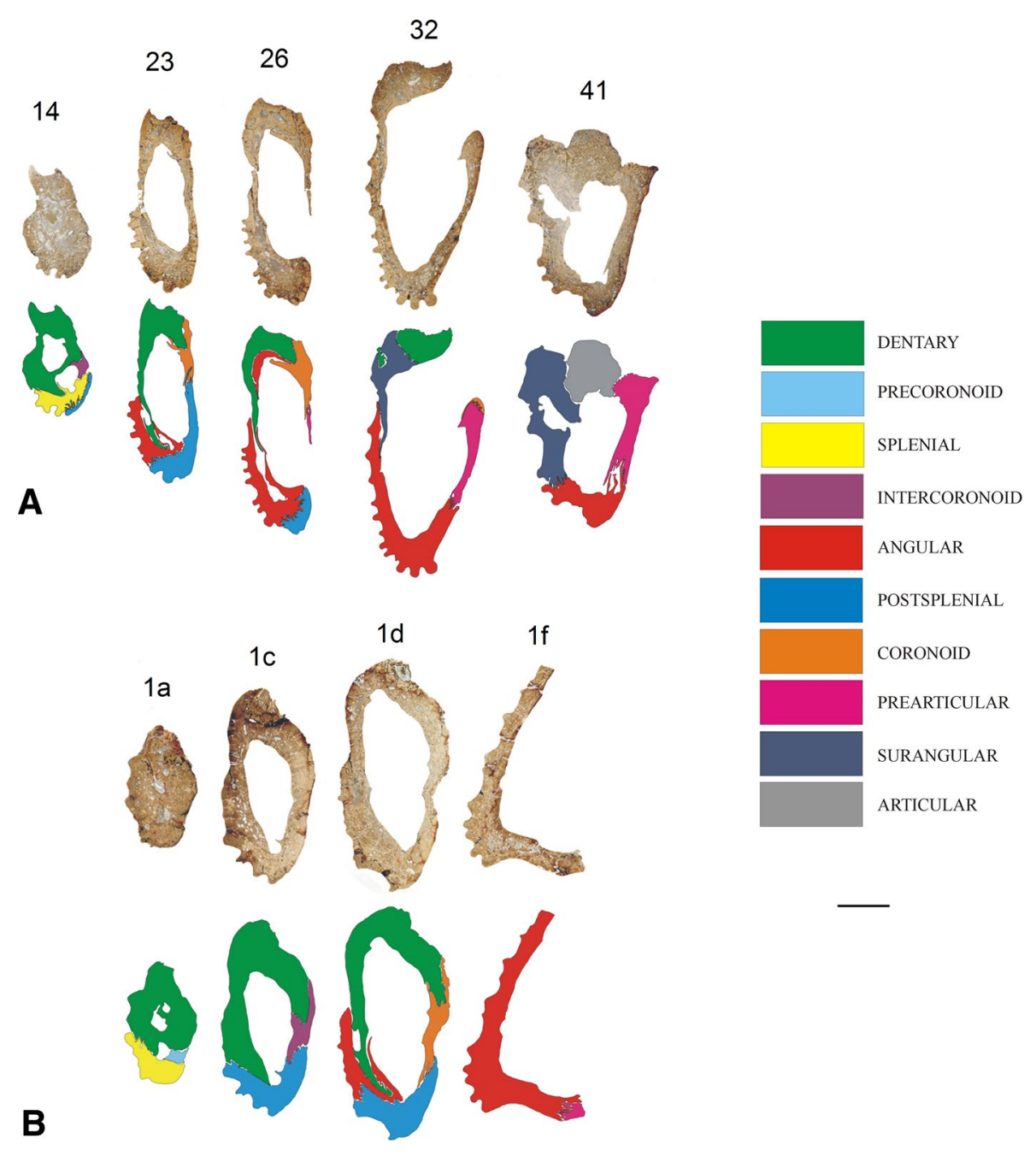

Fig. 4 Photographs and schematic drawings of selected thin sections of specimens UOPB 01145 (a) and UOPB 01027 (b). Scale bar equals $10 \mathrm{~mm}$. a No. 14, shallowly interdigitated dentary-intercoronoid suture, tongue and groove dentary-splenial suture, shallowly interdigitated intercoronoid-splenial suture and interdigitated postsplenial-splenial suture; no. 23, overlapping angular-dentary suture, interdigitated angular-postsplenial suture, tongue and groove coronoid-dentary suture and interdigitated coronoid-postsplenial suture; no. 26, overlapping angular-dentary suture, interdigitated angular-postsplenial suture, shallowly interdigitated coronoid-dentary suture and interdigitated coronoid-prearticular suture; no. 32, interdigitated angular-prearticular suture, overlapping angular-surangular suture, interdigitated coronoid-prearticular suture and shallowly inter-

A shallowly interdigitated suture occurs over the entire length of the dentary contact: dentary-splenial, dentaryprecoronoid (Fig. 5a, b), coronoid-dentary and dentarysurangular. Shallowly interdigitated sutures have been noted additionally at the following contacts: precoronoid-splenial, intercoronoid-splenial (Fig. 5g, h) and postsplenial-splenial.

Overlapping types can be observed in the central part of the mandible, at the angular-dentary (Fig. 6a), digitated dentary-surangular suture; no. 41, interdigitated angularprearticular suture, interdigitated angular-surangular suture, abutting articular-prearticular suture and abutting articular-surangular suture; b No. 1a, shallowly interdigitated dentary-precoronoid suture, shallowly interdigitated dentary-splenial suture and abutting precoronoidsplenial suture; no. 1c, tongue and groove dentary-intercoronoid suture, overlapping dentary-postsplenial suture and interdigitated intercoronoid-postsplenial suture; no. 1d, overlapping angular-dentary suture, interdigitated angular-postsplenial suture, tongue and groove coronoid-dentary suture and interdigitated coronoid-postsplenial suture; no. 1f, interdigitated angular-prearticular suture. no. number of section

angular-surangular (Fig. 6b), dentary-postsplenial (Fig. 6c), coronoid-postsplenial and coronoid-prearticular contact.

Tongue and groove suture types have been recognised only at the dentary contact: dentary-splenial, dentary-intercoronoid (Figs. 5g, 6d, e) and coronoid-dentary.

The abutting suture type occurs especially in the articular part of the mandible: at the articular-surangular and articular-prearticular contacts (Fig. 6f, g). Moreover, one sample 

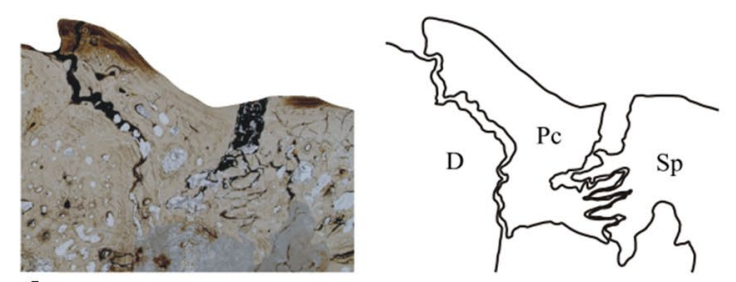

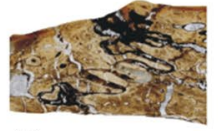

C
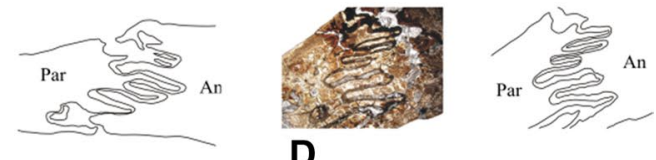

D
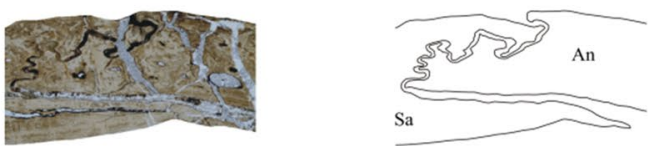

$\mathbf{E}$

B

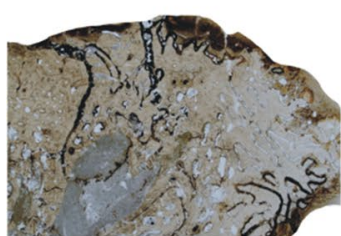

G
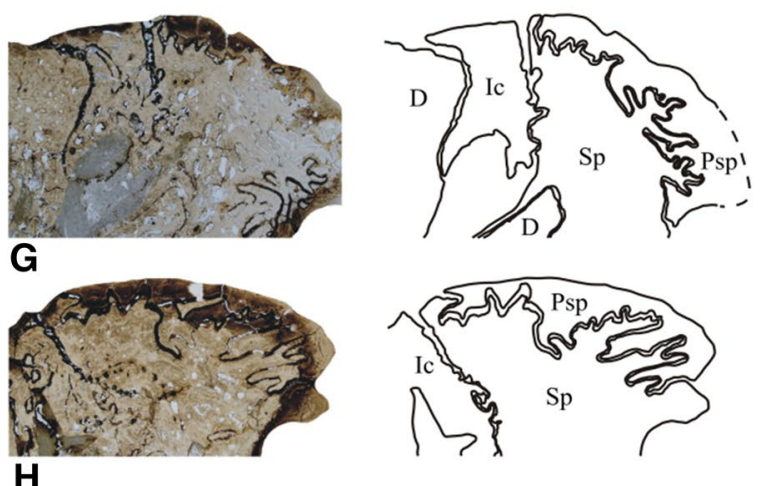

Fig. 5 Photographs and interpretative line drawing of the variable morphology of selected sutures in specimens UOPB 01144 (a, b, g, h), UOPB 01145 (c, e, f) and UOPB 01027 (d). Scale bar equals $5 \mathrm{~mm}$. a UOPB 01144 , no. 4, shallowly interdigitated dentary-precoronoid suture and interdigitated precoronoid-splenial suture; b UOPB 01144, no. 5, shallowly interdigitated dentary-precoronoid suture and interdigitated precoronoid-splenial suture; c UOPB 01145, no. 32, interdigitated angular-prearticular suture; d UOPB 01027, no. 1f, interdigitated angular-prearticular suture, e UOPB 01145, no. 34,

(UOPB 01027) presents an abutting type of suture at the precoronoid-splenial contact.

The presence of distinct and dense clumps of Sharpey's fibres has been noted in all sutural edges (Table 2). The longest and thickest fibres are present in the symphyseal region, and in the posterior part of the mandible, and they are well visible at the following contacts: dentary-splenial, postsplenial-splenial, coronoid-postsplenial, angularpostsplenial and articular-prearticular sutures (Fig. 7a-f; Table 2). The inclination angle of Sharpey's fibres in interdigitated sutures varies, starting from near-perpendicular as in the dentary-splenial (Fig. 7a; Table 2) to more oblique as in the postsplenial-splenial (Fig. 7b; Table 2), coronoidpostsplenial (Fig. 7c; Table 2) and angular-postsplenial (Fig. 7d; Table 2). Moreover, interdigitated sutures show the longest and most densely packed bundles of Sharpey's fibres, whereas in the tongue-and-groove, overlapping, and shallowly interdigitated sutures these are very short, and interdigitated angular-surangular suture; f UOPB 01145, no. 23, interdigitated angular-postsplenial suture, g UOPB 01144, no. 6, tongue and groove dentary-intercoronoid suture, shallowly interdigitated intercoronoid-splenial suture and interdigitated postsplenial-splenial suture; h UOPB 01144, no. 7, shallowly interdigitated intercoronoidsplenial suture and interdigitated postsplenial-splenial suture. An angular, $D$ dentary, $I c$ intercoronoid, $P a r$ prearticular, $P c$ precoronoid, $P s p$ postsplenial, $S a$ surangular, $S p$ splenial, no. number of section

difficult to follow along all bony edges. Their orientation in the shallowly interdigitated type is radiating outwards at the apex of the interdigitation. In abutting sutures, mainly in the articular-prearticular (Fig. 7e; Table 2) and articularsurangular (Fig. 7f; Table 2), Sharpey's fibres occur along the entire sutural edges in very dense bundles, resembling interwoven structural fibres (ISF).

\subsection{Sutural changes along the mandible}

External traces of mandibular sutures are well visible (especially in UOPB 01145) on the surface and individual bones are easily differentiated (Fig. 3a-g). Over their entire length the sutural courses are straight and constant both on the labial and lingual side. Only in the upper part of the coronoid-prearticular contact, does the sutural morphology become interdigitated (Fig. 3d); in the coronoid-intercoronoid (Fig. 3b) and dentary-surangular 


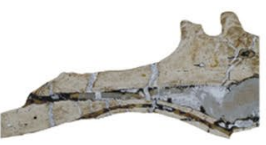

A

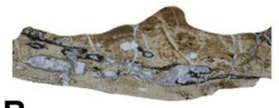

B

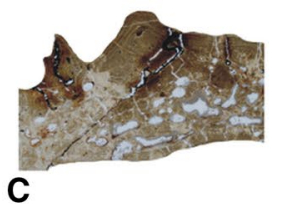

C

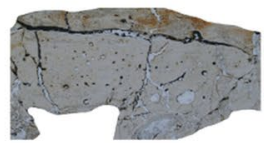

D

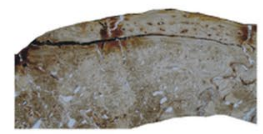

E
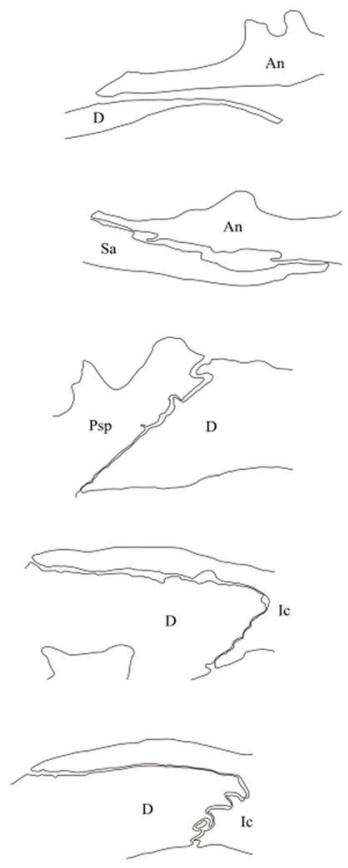

Fig. 6 Photographs and interpretative line drawing of cross sectional morphology of selected sutures in specimens UOPB $01145(\mathbf{a}, \mathbf{b}, \mathbf{d}$, g) and UOPB 01027 (c, e, f). Scale bar equals $5 \mathrm{~mm}$. a UOPB 01145 , no. 26, overlapping angular-dentary suture; b UOPB 01145, no. 31, overlapping angular-surangular suture; c UOPB 01027, no. 1c, overlapping dentary-postsplenial suture; d UOPB 01145 , no. 18, tongue and groove dentary-intercoronoid suture; e UOPB 01027, no. 1c, tongue and groove dentary-intercoronoid suture; f UOPB 01027, no. 1 e, abutting articular-prearticular suture and abutting articular-surangular suture; g UOPB 01145, no. 43, abutting articular-prearticular suture and abutting articular-surangular suture. An angular, $\mathrm{Ar}$ articular, $D$ dentary, $I c$ intercoronoid, $P a r$ prearticular, $P s p$ postsplenial, $S a$ surangular, no. number of section contacts (Fig. 3f) the sutural connection becomes tongueand-groove. However, in cross sections the variability of mandibular sutural typology in Metoposaurus krasiejowensis is high, both on the labial and lingual sides. The highest variation can be observed along the dentary, with four suture typologies distinguished. On the lingual surface, the dentary contacts other bones as a shallowly interdigitated suture, i.e., in the dentary-precoronoid (Fig. 5a, b), and as tongue and groove sutures, especially in the dentary-intercoronoid (Figs. 5g, 6d, e). However, on the labial surface, interdigitated, shallowly interdigitated and overlapping sutures (Fig. 6a) are present at the following contacts: dentary-splenial, dentary-postsplenial, angulardentary and dentary-surangular.

Moreover, in many cases, suture morphology changes along the same contact between two bones, for instance in the dentary-splenial. This is interdigitated anteriorly, but changes into a tongue and groove suture type posteriorly and finally becomes shallowly interdigitated. The precoronoidsplenial is shallowly interdigitated anteriorly, but becomes interdigitated posteriorly (Fig. 5a, b), while the postsplenialsplenial is interdigitated anteriorly (Fig. 5g, h), becoming shallowly interdigitated posteriorly. The angular-surangular present an overlapping suture type anteriorly (Fig. 6b), but evolve into an interdigitated suture posteriorly (Fig. 5e). This tendency of change in sutural morphology, i.e., a predominance of shallowly interdigitated suture in the anterior part of the mandible, and interdigitated sutures in its posterior part has been noted in all three specimens, in particular in UOPB 01145 and UOPB 01027.

\section{Discussion}

\subsection{Interpretation of suture biomechanical function}

External traces of sutures occurring at the mandibular surface appear as straight connections between adjacent bones, and their morphology is usually constant along the entire length of the mandible. In contrast, the cross sectional morphology of sutures varies along the length of even a single contact. Thus, only sutures visible in cross section are interpreted where their biomechanical function is concerned. Markey and Marshall (2007b) demonstrated that cross sectional suture morphology was a better indicator for 

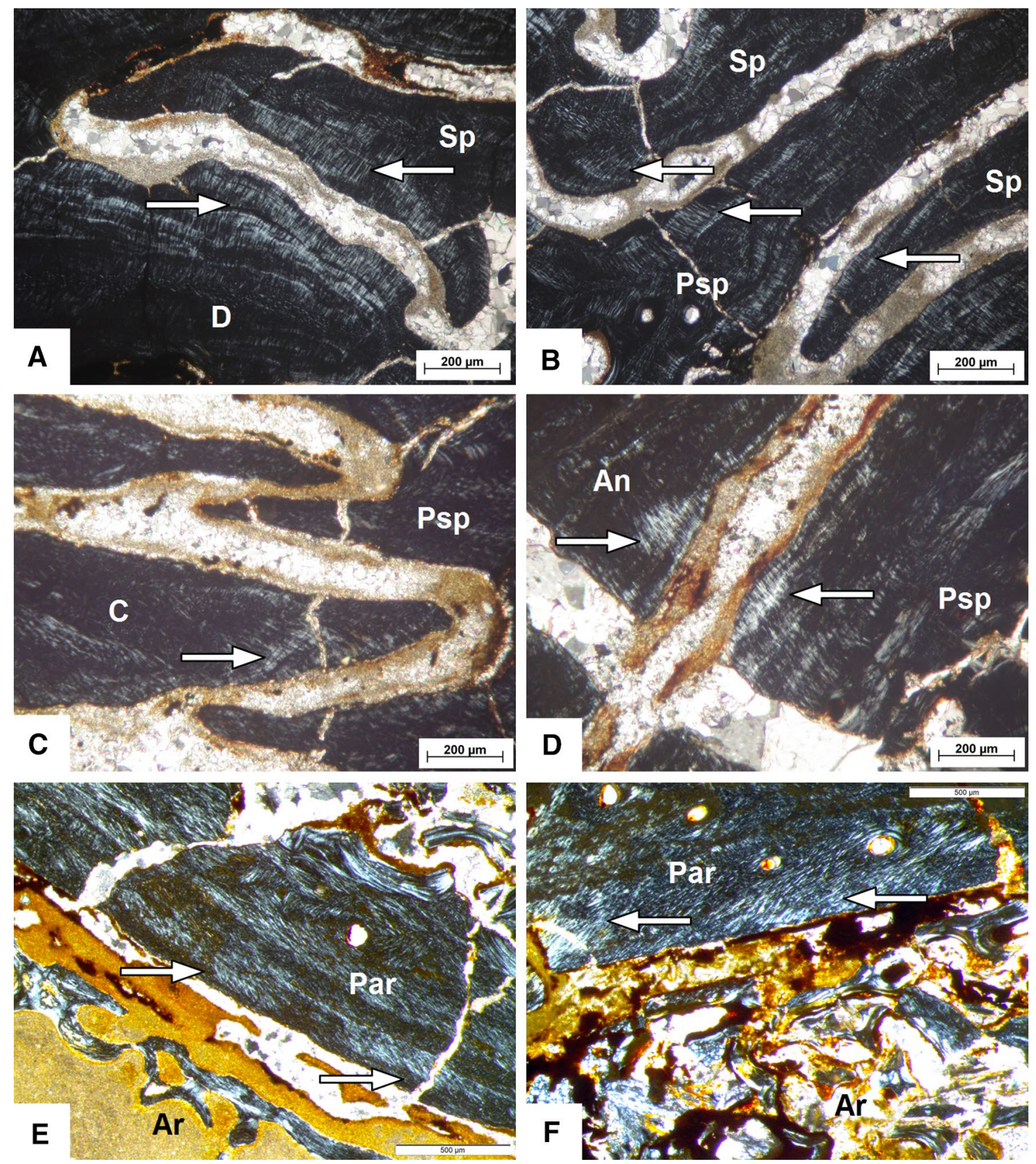

Fig. 7 Distinct Sharpey's fibres in polarised light along the sutural edges of mandibular bones. a UOPB 01144, no. 6, interdigitated dentary-splenial suture; b UOPB 01144, no. 6, interdigitated postsplenial-splenial suture; c UOPB 01027 , no. 1d, interdigitated coronoid-postsplenial suture; d UOPB 01027, no. 1d, interdigitated

deduction of its function than were sutures visible on the surface of the bone.

The interpretation of biomechanical function of mandibular sutures in Metoposaurus krasiejowensis was conducted following previous studies based on non-amniote cranial biomechanics (Markey et al. 2006; Jasinoski et al. 2010a; Porro et al. 2015). Additional information on loading on angular-postsplenial suture; e UOPB 01145, no. 43, abutting articular-prearticular suture; f UOPB 01027, no. 1e, abutting articularprearticular suture. An angular, $A r$ articular, $C$ coronoid, $D$ dentary, Par prearticular, $P s p$ postsplenial, $S p$ splenial, no. number of section

interdigitated sutures comes from Sharpey's fibres: obliquely oriented fibres on the direction of the apex of the interdigitation indicate compression and in shallowly interdigitated sutures, which experience tension, the fibres radiate outwards at the apex of the interdigitation (Rafferty and Herring 1999; Herring and Teng 2000; Jasinoski et al. 2010a). Well-mineralised Sharpey's fibres occur along sutural 
edges in all samples examined, but not in all cases can their arrangements be determined. In deeply interdigitated sutures (Fig. 7a-d) they are long and packed in numerous clumps. Additionally, their arrangements and direction of orientation is easy to follow as perpendicular or oblique to the apex of the interdigitation. Numerous and long Sharpey's fibres are predominant in interdigitated sutures and may suggest that this type of bone connection was adapted to resist strong compression stresses acting on the bone, and may be the most heavily involved one during feeding.

In contrast, Sharpey's fibres are very short, and less numerous in overlapping, tongue-and-groove, and shallowly interdigitated sutures. For this reason, their arrangement is particularly difficult to determine and follow along these types of joints. Partially preserved clumps of Sharpey's fibres in shallowly interdigitated sutures represent an outwardly radiating arrangement at the apex of the interdigitation, while in overlapping sutures Sharpey's fibres are usually oriented perpendicular to the edges of the bone. The less abundant accumulation of Sharpey's fibres in these sutural morphologies may suggest lesser stress capability in these types of sutures. In abutting sutures (Fig. 7e, f), especially in the articular part of the mandible, Sharpey's fibres occur along the entire length of bony edges with a differentiated direction in their arrangement. Moreover, dense bundles of Sharpey's fibres occurring in abutting sutures at the articular connection may have caused elastic mobility of this joint, and counteracting tension stresses during jaw opening.
The most problematic biomechanical interpretation concerns overlapping sutures. Several authors (e.g., Markey et al. 2006; Jasinoski et al. 2010a) recognised that this type of suture was capable to resist both compression and tension, whereas Porro et al. (2015) suggested the association of this suture with torsion and shearing. In Metoposaurus krasiejowensis overlapping sutures are located in the middle part of the jaw ramus, both on the lingual and labial sides (Fig. 8; Table 2), but Sharpey's fibres present there invariably are short, but well developed and perpendicular to the edges of the bone. Generally, in long bones, fibres that are aligned longitudinally relative to the load are associated with tension, while compression is most effectively resisted by fibres that are aligned transversely (Ascenzi and Bonucci 1967, 1968; Vincentelli and Evans 1971). Overlapping sutures are aggregated in the medial part of the lower jaw, which in Temnospondyli has the shape of relatively straight, but long, cylinder. Thus, it could be assumed that this region experienced various forces related to mouth opening and eventually lateral bending of the rami. In this case the overlapping joints should should work as a stable but elastic structure of the medial region and should be adapted to counteract variable loads.

Sutures associated with tension occur in particular along the entire lingual length of the dentary and at the articular, prearticular, and surangular contacts (Figs. 5a, $\mathrm{b}, \mathrm{g}, 6 \mathrm{~d}-\mathrm{g}, 8$ ). The symphyseal region was elastic (Sulej 2007), meaning that the tensed sutures across the dentary

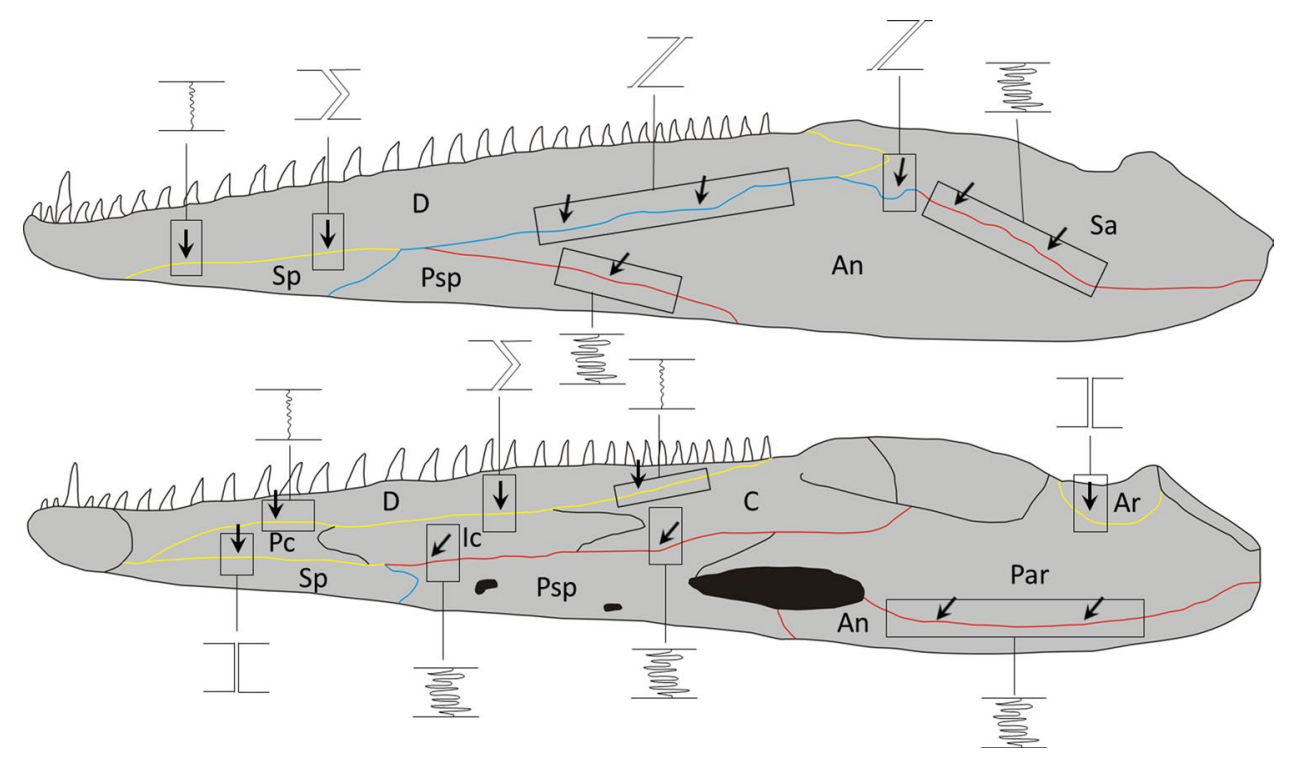

Fig. 8 Schematic illustration of the mandible of Metoposaurus krasiejowensis with interpretative demonstration of stress distribution. An angular, $A r$ articular, $C$ coronoid, $D$ dentary, $I c$ intercoronoid, $P a r$ prearticular, $P c$ precoronoid, $P s p$ postsplenial, $S a$ surangular, $S p$ splenial. Red lines indicate areas undergoing compression stress in cross section; yellow lines indicate areas undergoing tension stress in cross section; blue lines indicate areas undergoing variable loads (tension and compression or torsion and shear) in cross section; black arrows indicate areas of well-visible accumulations of Sharpey's fibres, and slope of the arrows shows accurate orientation of Sharpey's fibres along the sutural edges 
may have been adapted to permit the jaws to open very wide during feeding. Wide opening of the mouth was proposed for metoposaurids (Sulej 2007), in a similar fashion to other groups (see below). The medial part of the mandible was under the influence of variable stresses, mainly along the labial part of the dentary and in the anterior part of the angular (Figs. 6a-c, 8). The posterior part of the mandible was subject to compression, especially in the angular, surangular and prearticular (Figs. 5a-f, 8). The compression impact in these areas may have resulted from muscle insertion in these areas (Sulej 2007) and may indicate adaptation to generate great biting capabilities. The presence of strong mandibular muscle attachment is additionally supported by the occurrence of very numerous and densely packed Sharpey's fibres (Gruntmejer 2015). Such abundant accumulations of Sharpey's fibres in these areas suggest that the most anterior and posterior regions of the mandible were elastic, playing a significant role during feeding behaviour.

Another issue is the presence of interwoven structural fibres (ISF) along the sutural surfaces of the prearticular (Fig. 7e, f) and the surangular with the articular. The prearticular and surangular are dermal bones, i.e., they ossify directly from soft tissues without a cartilaginous predecessor, whereas the articular undergoes periosteal ossification. Thus, the presence of ISF in this case represent the connection between two ossification systems. However, IFS also represent a strong connection of bone with the soft tissues, increasing the biomechanical strength of the bony tissue and, similar to the skull dermal bones of Metoposaurus krasiejowensis (Gruntmejer et al. 2016), the occurrence of ISF in mandible dermal bones also indicates their metaplastic origin.

\subsection{Comparison of sutural morphology between the skull and mandible of Metoposaurus krasiejowensis and functional interpretation}

The majority of cranial sutures studied in one of the skulls (UOPB 01029) of Metoposaurus krasiejowensis were defined as interdigitated (Gruntmejer 2012), which are associated with compression (Rafferty and Herring 1999; Markey et al. 2006; Markey and Marshall 2007a, b; Jasinoski et al. 2010b). Moreover, sutural morphology does not change along the skull bones (Gruntmejer 2012). A predominance of interdigitated sutures across the postorbital and medial part of the skull roof was confirmed in other early non-amniotes (Kathe 1997). Interestingly, in the entire skull examined, sutures associated with tension (i.e., abutting or tongueand-groove) do not occur (Gruntmejer 2012). In contrast to the skull, where the external traces of sutures between skull bones are fused and invisible (Gruntmejer 2012; Gruntmejer et al. 2016), the external course of all sutures in the mandible is visible and can be followed. In addition, well-mineralised Sharpey's fibres occur in dense bundles along the periphery of the sutural edges. This indicates that sutures were not fully ossified and still elastic. Based on this observation, they probably could absorb strain and stress. This feature could be important in our understanding of the mechanical system for flat and relatively large cranial bones, but also in mandibles. Together with the highly fibred matrix of dermal bones (Gruntmejer 2015; Gruntmejer et al. 2016), the entire skull and lower jaw were strongly, yet elastically, connected to the external cover of the body, but also the bones to each other. In contrast to the skull, mandibular sutures in Metoposaurus reveal a complex variability as far as cross sectional morphology is concerned and suggest the important role of the mandible in feeding behaviours.

\section{Conclusions}

The mandible sutures in Metoposaurus krasiejowensis are of different types: interdigitated, shallowly interdigitated, overlapping, tongue and groove and abutting. A comparison of the morphology of mandibular sutures in three specimens of Metoposaurus krasiejowensis indicates that suture morphology varies along the mandible. The morphology of mandibular sutures reveals the particular importance of the mandible during feeding. Extensive variability of sutural morphology along the entire mandible of Metoposaurus krasiejowensis suggests a complex loading regime, including simultaneous compression and tension regimes. Due to a lack of histological data of cross sectional morphology of mandibular sutures and related biomechanical functions in temnospondyls, it is difficult to correlate the results found for Metoposaurus krasiejowensis with other temnospondyl taxa. Additional studies are called for, inclusive of quantitative and computational analyses. For the time being, we can state that, on the basis of current investigations of the skull of Metoposaurus krasiejowensis, including dermal bone histology, cranial suture morphology and computational biomechanics (finite element simulations), these animals were capable of direct biting of prey items by using different feeding behaviours such as ambush strategy (bilateral bite) and active predation by lateral head movements (lateral bite).

Acknowledgements The authors are grateful to Michał Jankowiak (Adam Mickiewicz University, Institute of Geology, Poland) for preparation of thin sections and to John Jagt (Natuurhistorisch Museum Maastricht, Maastricht) for improving the English. J. Fortuny acknowledges receiving a postdoc Grant, "Beatriu de Pinós" 2014-BP-A 00048 (Generalitat de Catalunya), the Spanish Ministerio de Economía, Industria y Competitividad, the European Regional Development Fund of the European Union (MINECO/FEDER EU, project CGL201454373-P) and the CERCA Programme (Generalitat de Catalunya). We thank also both reviewers (Michael Buchwitz and Bryan Gee) and the 
invited editor (Jean-Sébastien Steyer) for all comments which greatly improved our paper.

Open Access This article is distributed under the terms of the Creative Commons Attribution 4.0 International License (http://creativeco mmons.org/licenses/by/4.0/), which permits unrestricted use, distribution, and reproduction in any medium, provided you give appropriate credit to the original author(s) and the source, provide a link to the Creative Commons license, and indicate if changes were made.

\section{References}

Ascenzi, A., \& Bonucci, E. (1967). The tensile properties of single osteons. The Anatomical Record, 158, 375-386.

Ascenzi, A., \& Bonucci, E. (1968). The compressive properties of single osteons. The Anatomical Record, 161, 377-391.

Bodzioch, A., \& Kowal-Linka, M. (2012). Unraveling the origin of the Late Triassic multitaxic bone accumulation at Krasiejów (S Poland) by diagenetic analysis. Palaeogeography, Palaeoclimatology, Palaeoecology, 346(347), 25-36.

Bolt, J. R., \& Chatterjee, S. (2000). A new temnospondyl amphibian from the Late Triassic of Texas. Journal of Paleontology, 74, 670-683.

Brusatte, S. L., Butler, R. J., Mateus, O., \& Steyer, J. S. (2015). A new species of Metoposaurus from the Late Triassic of Portugal and comments of the systematics and biogeography of metoposaurid temnospondyls. Journal of Vertebrate Paleontology, 35, e912988.

Carroll, R. L. (1964). Early evolution of the dissorophid amphibians. Bulletin of the Museum of Comparative Zoology, 131, 161-250.

Chakravorti, S., \& Sengupta, D. P. (2016). Indian metoposaurid amphibians: morphometry, taxonomy and dispersal. In F. Holwerda, A. Madern \& D. Voeten et al. (Eds.), XIV Annual Meeting of European Association of Vertebrate Palaeontologists-Abstract Book (p. 96).

Chinsamy, A., \& Raath, M. A. (1992). Preparation of fossil bone for histological examination. Palaeontologia Africana, 29, 39-44.

Chowdhury, T. R. (1965). A new metoposaurid amphibian from the Upper Triassic Maleri Formation of Central India. Philosophical Transactions of the Royal Society of London, Series B, 250(761), $1-52$.

Dutuit, J. M. (1976). Introduction à l'étude paléontologique du Trias continental marocain. Descriptions des premiers Stégocéphales receuillis dans le couloir d'Argana (Atlas Occidental). Mémoires du Muséum national d'Histoire naturelle Paris, 36, 1-253.

Dutuit, J. M. (1978). Description de quelques fragments osseux provenant de la région de Folakara (Trias supérieur malgache). Bulletin du Muséum national d'Histoire naturelle Paris, 69, 79-89.

Dzik, J., \& Sulej, T. (2007). A review of the early Late Triassic Krasiejów biota from Silesia, Poland. Palaeontologia Polonica, 64, 3-27.

Dzik, J., Sulej, T., Kaim, A., \& Niedźwiedzki, R. (2000). Późnotriasowe cmentarzysko kręgowców lądowych w Krasiejowie na Śląsku Opolskim. Przeglad Geologiczny, 48, 226-235.

Fortuny, J., Marcé-Nogué, J., De Esteban-Trivigno, S., Gil, L., \& Galobart, Á. (2011). Temnospondyli bite club: ecomorphological patterns of the most diverse group of early tetrapods. Journal of Evolutionary Biology, 24, 2040-2054.

Fortuny, J., Marcé-Nogué, J., Gil, L., \& Galobart, Á. (2012). Skull mechanics and the evolutionary patterns of the otic notch closure in capitosaurs (Amphibia: Temnospondyli). The Anatomical Record, 295, 1134-1146.

Fortuny, J., Marcé-Nogué, J., Heiss, E., Sanchez, M., Gil, L., \& Galobart, À. (2015). 3D bite modeling and feeding mechanics of the largest living amphibian, the Chinese giant salamander Andrias davidianus (Amphibia: Urodela). PLoS One, 10, e0121885.

Fortuny, J., Marcé-Nogué, J., \& Konietzko-Meier, D. (2017). Feeding with Late Triassic metoposaurids: A 3D finite element analysis approach. Journal of Anatomy, 230, 752-765.

Fortuny, J., Marcé-Nogué, J., Steyer, J. S., De Esteban-Trivigno, S., Mujal, E., \& Gil, L. (2016). Comparative 3D analyses and palaeoecology of giant early amphibians (Temnospondyli: Stereospondyli). Scientific Reports, 6, 30387.

Francillon-Vieillot, H., de Buffrénil, V., Castanet, J., Géraudie, J., Meunier, F. J., Sire, J. Y., et al. (1990). Microstructure and mineralization of vertebrate skeletal tissues. In J. G. Carter (Ed.), Skeletal biomineralization: patterns, processes and evolutionary trends (Vol. I, pp. 471-530). New York: Van Nostrand Reinhold.

Gruntmejer, K. (2012). Morphology and function of cranial sutures of the Triassic amphibian Metoposaurus diagnosticus (Temnospondyli) from southwest Poland. In E. Jagt-Yazykova, J. Jagt, A. Bodzioch, et al. (Eds.), Krasiejów-Palaeontological inspirations (pp. 34-54). Bytom: ZPW Plik.

Gruntmejer, K. (2015). Mandible histology in Metoposaurus diagnosticus krasiejowensis (Amphibia, Temnospondyli) from the Upper Triassic of Poland—Preliminary results. In J. Jagt, G. Hebda \& S. Mitrus et al. (Eds.), XIII Annual Meeting of European Association of Vertebrate Palaeontologists-Abstract Book (p. 28).

Gruntmejer, K., Konietzko-Meier, D., \& Bodzioch, A. (2016). Cranial bone histology of Metoposaurus krasiejowensis (Amphibia, Temnospondyli) from the Late Triassic of Poland. PeerJ, 4, e2685.

Gruszka, B., \& Zieliński, T. (2008). Evidence for a very low-energy fluvial system: A case study from the dinosaur-bearing Upper Triassic rocks of southern Poland. Geological Quarterly, 52, 239-252.

Haridy, Y., LeBlanc, A. R., \& Reisz, R. R. (2017a). The Permian reptile Opisthodontosaurus carrolli: A model for acrodont tooth replacement and dental ontogeny. Journal of Anatomy, 232, 371-382.

Haridy, Y., MacDougall, M. J., \& Reisz, R. R.. The lower jaw of the Early Permian parareptile Delorhynchus, first evidence of multiple denticulate coronoids in a reptile. Zoological Journal of the Linnean Society (in press). https://doi.org/10.1093/zoolinnean/zlx085

Heaton, M. J. (1979). Cranial anatomy of primitive captorhinid reptiles from the Late Pennsylvanian and Early Permian, Oklahoma and Texas. Oklahoma Geological Society Bulletin, 127, 1-84.

Herring, S. W., \& Teng, S. (2000). Strain in the braincase and its sutures during function. American Journal of Physical Anthropology, 112, 575-593.

Hunt, A. P. (1993). Revision of the Metoposauridae (Amphibia: Temnospondyli) and description of a new genus from western North America. Museum of Northern Arizona Bulletin, 59, 67-97.

Jasinoski, S. C., Rayfield, E. J., \& Chinsamy, A. (2010a). Functional implications of dicynodont cranial suture morphology. Journal of Morphology, 271, 705-728.

Jasinoski, S. C., \& Reddy, B. D. (2012). Mechanics of cranial sutures during simulated cyclic loading. Journal of Biomechanics, 45, 2050-2054.

Jasinoski, S. C., Reddy, B. D., Louw, K. K., \& Chinsamy, A. (2010b). Mechanics of cranial sutures using the finite element method. Journal of Biomechanics, 43, 3104-3111.

Jupp, R., \& Warren, A. A. (1986). The mandibles of the Triassic temnospondyl amphibians. Alcheringa, 10, 99-124.

Kathe, W. (1995). Morphology and function of the sutures in the dermal skull roof of Discosauriscus austriacus Makowsky 1876 (Seymouriamorpha; Lower Permian of Moravia) and Onchiodon labyrinthicus Geinitz 1861 (Temnospondyli; Lower Permian of Germany). Geobios, Mémoire Spécial, 19, 255-261.

Kathe, W. (1997). Comparative morphology and functional interpretations of the sutures in the dermal skull roof of temnospondyl 
amphibians. Zoological Journal of the Linnean Society, 126, $1-39$.

Konietzko-Meier, D., Bodzioch, A., \& Sander, P. M. (2013). Histological characteristics of the vertebral intercentra of Metoposaurus diagnosticus (Temnospondyli) from the Upper Triassic of Krasiejów (Upper Silesia, Poland). Transactions of the Royal Society of Edinburgh, Earth and Environmental Sciences, 103, $1-14$.

Konietzko-Meier, D., Danto, M., \& Gądek, K. (2014). The microstructural variability of the intercentra among temnospondyl amphibians. Biological Journal of the Linnean Society, 112, 747-764.

Konietzko-Meier, D., Gruntmejer, K., Marcé-Nogué, J., Bodzioch, A., \& Fortuny, J. (2018). Merging cranial histology and 3D-computational biomechanics: a review of the feeding ecology of a Late Triassic temnospondyl amphibian. PeerJ, 6, e4426.

Konietzko-Meier, D., \& Klein, N. (2013). Unique growth pattern of Metoposaurus diagnosticus krasiejowensis (Amphibia, Temnospondyli) from the Upper Triassic of Krasiejów, Poland. Palaeogeography, Palaeoclimatology, Palaeoecology, 370, 145-157.

Konietzko-Meier, D., \& Sander, P. M. (2013). Long bone histology of Metoposaurus diagnosticus (Temnospondyli) from the Late Triassic of Krasiejów (Poland) and its paleobiological implications. Journal of Vertebrate Paleontology, 33, 1003-1018.

Konietzko-Meier, D., \& Wawro, K. (2007). Mandibular dentition in the Late Triassic temnospondyl amphibian Metoposaurus. Acta Palaeontologica Polonica, 52, 213-215.

Lucas, S. G. (2015). Age and correlation of the Late Triassic tetrapods from southern Poland. Annales Societatis Geologorum Poloniae, $85,627-635$.

Lucas, S. G., Spielmann, J. A., \& Hunt, A. P. (2007). Bio-chronological significance of the Late Triassic tetrapods from Krasiejów, Poland. New Mexico Museum of Natural History and Science Bulletin, 41, 248-258.

Marcé-Nogué, J., Fortuny, J., De Esteban-Trivigno, S., Sánchez, M., Gil, L., \& Galobart, À. (2015). 3D computational mechanics elucidate the evolutionary implications of orbit position and size diversity of early amphibians. PLoS One, 10, e0131320.

Markey, M. J., Main, R. P., \& Marshall, C. R. (2006). In vivo cranial suture function and suture morphology in the extant fish Polypterus: Implications for inferring skull function in living and fossil fish. Journal of Experimental Biology, 209, 2085-2102.

Markey, M. J., \& Marshall, C. R. (2007a). Linking form and function of the fibrous joints in the skull: a new quantification scheme for cranial sutures using the extant fish Polypterus endlicherii. Journal of Morphology, 268, 89-102.

Markey, M. J., \& Marshall, C. R. (2007b). Terrestrial-style feeding in a very early aquatic tetrapod is supported by evidence from experimental analysis of suture morphology. Proceedings of the National Academy of Sciences, USA, 104, 7134-7138.

Murry, P. A. (1989). Paleoecology and vertebrate faunal relationships, of the Upper Triassic Dockum and Chinle formations, southwestern United States. In S. G. Lucas \& A. P. Hunt (Eds.), Dawn of dinosaurs in the American southwest (pp. 375-400). Alburquerque: New Mexico Museum of Natural History.
Neenan, J. M., Ruta, M., Clack, J., \& Rayfield, E. J. (2014). Feeding biomechanics in Acanthostega and across the fish-tetrapod transition. Proceedings of the Royal Society B, 281, 20132689.

Ochev, V. G. (1966). Systematics and phylogeny of capitosauroid labyrinthodonts. Saratov: Saratov State University Press. (in Russian).

Polley, B. P., \& Reisz, R. R. (2011). A new Lower Permian trematopid (Temnospondyli: Dissorophoidea) from Richards Spur, Oklahoma. Zoological Journal of the Linnean Society, 161, 789-815.

Porro, L. B., Rayfield, E. J., \& Clack, J. A. (2015). Descriptive anatomy and three-dimensional reconstruction of the skull of the early tetrapod Acanthostega gunnari Jarvik, 1952. PLoS One, 10, e0118882.

Racki, G., \& Szulc, J. (2014). Formacja grabowska-Podstawowa jednostka litostratygraficzna kajpru Górnego Śląska. Przeglad Geologiczny, 63, 103-113.

Rafferty, K. L., \& Herring, S. W. (1999). Craniofacial sutures: Morphology, growth, and in vivo masticatory strains. Journal of Morphology, 242, 167-179.

Ruta, M., \& Bolt, J. R. (2008). The brachyopoid Hadrokkosaurus bradyi from the early Middle Triassic of Arizona, and a phylogenetic analysis of lower jaw characters in temnospondyl amphibians. Acta Palaeontologica Polonica, 53, 579-592.

Schoch, R. R., \& Milner, A. R. (2000). Stereospondyli. In P. Wellnhofer (Ed.), Handbuch der Paläoherpetologie (Vol. 3B, pp. 1-203). Munich: F. Pfeil.

Sengupta, D. P. (1992). Metoposaurus maleriensis Roychowdhury from the Tiki Formation of Son-Mahanadi Valley of Central India. Indian Journal of Geology, 64, 300-305.

Sengupta, D. P. (2002). Indian metoposaurid amphibians revised. Paleontological Research, 6, 41-65.

Sulej, T. (2002). Species discrimination of the Late Triassic temnospondyl amphibian Metoposaurus diagnosticus. Acta Palaeontologica Polonica, 47, 535-546.

Sulej, T. (2007). Osteology, variability, and evolution of Metoposaurus, a temnospondyl from the Late Triassic of Poland. Palaeontologia Polonica, 64, 29-139.

Szulc, J., Racki, G., \& Jewuła, K. (2015a). Key aspects of the stratigraphy of the Upper Silesian middle Keuper, southern Poland. Annales Societatis Geologorum Poloniae, 85, 557-586.

Szulc, J., Racki, G., Jewuła, K., \& Środoń, J. (2015b). How many Upper Triassic bone-bearing levels are there in Upper Silesia (southern Poland)? A critical overview of stratigraphy and facies. Annales Societatis Geologorum Poloniae, 85, 587-626.

Teschner, E. M., Sander, P. M., \& Konietzko-Meier, D. (2018). Variability of growth pattern observed in Metoposaurus krasiejowensis humeri and its biological meaning. Journal of Iberian Geology, 44, 99-111.

Vincentelli, R., \& Evans, F. G. (1971). Relations among mechanical properties, collagen fibers, and calcification in adult human cortical bone. Journal of Biomechanics, 4, 193-201.

von Meyer, H. (1842). Labyrinthodonten-Genera. Neues Jahrbuch für Mineralogie, Geographie, Geologie und Petrefaktenkunde, 1842, 301-304.

\section{Affiliations}

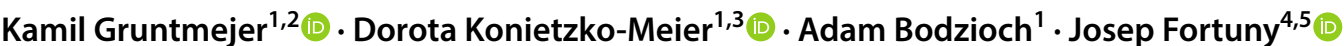

Kamil Gruntmejer

gruntmejerkamil@gmail.com
1 Department of Biosystematics, Laboratory of Palaeobiology, Opole University, Oleska 22, 45-052 Opole, Poland

2 European Centre of Palaeontology, Opole University, Oleska 48, 45-052 Opole, Poland 
3 Steinmann Institute, University of Bonn, Nussallee 8, 53115 Bonn, Germany

4 Centre de Recherches en Paléontologie de Paris, UMR 7207 CNRS-MNHN-UPMC, Muséum national d'Histoire naturelle, Bâtiment de Paléontologie, CP38, 8 rue Buffon, 75005 Paris, France
5 Institut Català de Paleontologia Miquel Crusafont, ICTA-ICP Building, c/de les columnes, s/n, 08193 Cerdanyola Del Vallès, Spain 